\title{
What are the Adequate Pedagogical Approaches for Teaching Scientific Disciplines? Physics as a Case Study
}

Mohammed Chekour

Mohamed Laafou

Rachid Janati-Idrissi

École Normale Supérieure, Tetouan, Morocco

Doi: 10.2478/jesr-2018-0025

\begin{abstract}
Different teaching approaches have revealed that teaching is a complex process, a profession that must adapt to the specific needs of the learners, the nature of the subject taught and the general context of the training. However, the act of learning is a common activity. In the educational sciences there is no one-sided approach to the didactics of physical sciences. Therefore, teachers of the physical sciences are invited to choose the appropriate pedagogical approaches based on the performance and limitations of each approach. In this article, we will review the literature of the main pedagogical approaches used to facilitate the acquisition of physical phenomena. On the basis of this study, we will highlight the added value of the combination of a relatively recent approach, based on historical investigation and simulation of physical phenomena.
\end{abstract}

Keywords: physics; didactics; pedagogical approaches; historical-investigation; simulation

\section{Introduction}

The problem of learning and the teaching of sciences is worrying. It has been subject to debate for decades (Chekour, Laafou, \& Janati-Idrissi, 2015b). Around the world, there is a decline of youth interest in science. There are diverse and complex reasons why young people are not interested in science (Griethuijsen et al., 2015; Leal, Leal, \& Fernandes, 2010). Legendre points out that the abstract nature of scientific knowledge hinders the acquisition of scientific concepts (Legendre, 1994). Research shows that the source of the problem lies in the difficulty of achieving the objectives of experiments in laboratories (Hofstein, 2017). Other researches emphasize the danger of learners' conceptions in the teaching and learning process (Taber, 2017). From another perspective, studies have shown that the problem lies not only in the knowledge itself, but also in the teaching practices (Ma, Fulmer, \& Liang, 2017). For this reason, several researchers were interested in the development of pedagogical approaches to make effectively teaching science and to increase learners' motivation (Chekour, Laafou, \& Janati-Idrissi, 2015a; Heering \& Höttecke, 2014). Fayolle and Verzat (2009) identify three main stages in what characterizes the general evolution of teaching approaches: they observe a shift from traditional logic of mere transmission of knowledge, to a logical transfer of capabilities with the Objective - based approach, then a logic of developing skills through practical training. In parallel with these three main stages, the projectbased approach and the problem-solving approach have taken a remarkable place in the work of didactics, especially in the learning of scientific disciplines. In the last two decades, a new 
pedagogical approach, known as historical investigation, has developed for the scientific disciplines. Kipnis (2002) mentioned that with this approach, students will have the chance to become real scientists who identify problems, formulate hypotheses, actively participate in the experiment, analyze the results and discuss the conclusions with their peers.

In this article, we will discuss the literature of the main pedagogical approaches to make the so-called hard sciences more attractive. This discussion presents the advantages and limitations of each approach. The objective of this work is to contribute to making the physical sciences more agreeable by investigating in pedagogical approaches and in educational technologies.

\section{The Pedagogical Approaches in the Literature}

Referring to the references on pedagogical approaches, one can only observe the superiority of English-speaking sources on French-language sources. Table 1 shows the difference between these two sources and keywords used in Google Scholar. This table also shows that few authors have written about historical investigation. Moreover, we have not found, in the French literature, references on the approach of historical investigation. That's why we retained the English references.

Table 1: number of references in Google Scholar (october 2017)

\begin{tabular}{|c|c|c|c|}
\hline \multicolumn{4}{|c|}{ Educational Approaches } \\
\hline \multicolumn{2}{|r|}{ In French } & \multicolumn{2}{|c|}{ In English } \\
\hline In the article & In the title of the article & In the article & In the title of the article \\
\hline \multicolumn{2}{|c|}{ "approche par objectifs" } & \multicolumn{2}{|c|}{ "Objective - based approach " } \\
\hline 421 & 10 & 659 & 12 \\
\hline \multicolumn{2}{|c|}{ "approche par compétences" } & \multicolumn{2}{|c|}{ "Skills-based approach" } \\
\hline 4340 & 11 & 4470 & 90 \\
\hline \multicolumn{2}{|c|}{ " Approche par projet" } & \multicolumn{2}{|c|}{ "project-based approach" } \\
\hline 485 & 15 & 9280 & 315 \\
\hline \multicolumn{2}{|c|}{ "approche par résolution de problèmes" } & \multicolumn{2}{|c|}{ "Problem solving-based approach" } \\
\hline 123 & 0 & 148 & 3 \\
\hline \multicolumn{2}{|c|}{ "Approche d'investigation historique" } & \multicolumn{2}{|c|}{ "Historical-investigative approaches" } \\
\hline 0 & 0 & 75 & 1 \\
\hline
\end{tabular}

\section{Objective Based Approach}

The objective-based approach is still very present in all fields of education (Bates, 2015). Historically, this pedagogy was founded by Ralph Tyler in 1935 (Sardo-Brown, 1990). A learning objective is a statement of intent that describes what the learner will do after learning (Raynal, Rieunier, Postic, \& Françaises, 1997). Objectives are presented as students' behavior. Thus, the formulations of these objectives refer to activities from the point of view of the student and not from the point of view of the teacher's project, which is a similarity with the behaviourist theory that is concerned with the study of observable behaviors of students.

In this approach, the objectives are broken down into general, specific and operational (Mager \& Décote, 1971). Students' success in this approach depends on the achievement of specific objectives. However, the majority of these students lose the thread in their learning. Indeed, the objective-based approach does not offer global tasks and therefore does not offer learners a global view of what they are learning.

\section{Competency Approach}

Carette, Defrance and Kahn (2006) argue that there is a difference between competency and pedagogy-based approaches. This latter invites student to work on operations that are too partial, which does not allow them to grasp the meaning of learning. On the other hand, the competency- 
based approach is committed to making pupils work on global activities that are related to students' everyday life. To implement a competency-based approach, certain principles must be respected. According to Lasnier (2000), this approach is characterized by: comprehensiveness, construction, application, significance and transfer. According to Carette (2008), a student will be competent if he is able to show his ability in facing new life situations.

There is no methodology for the development of competency-based programs. This approach does not refer to a particular teaching method. Learning is seen as a personal process with a cognitive, emotional and social character. As a result, several pedagogical strategies and techniques can be used to support learning through using the competency-based approach (Bates, 2015).

The competency-based approach requires teachers to make students able to mobilize their learning, while this cognitive activity of mobilization remains immeasurable. Learning to mobilize becomes the central objective in a competency-based approach and raises a major question: how to get students to use what they have actually learned in new circumstances? Without this learning, the concept of competence becomes really dangerous and might lead to further discrimination between students (Carette, 2008).

\section{Project- Based Approach}

Project- based approach is a practice of active pedagogy that brings learning through the realization of a concrete production. Projects are generally based on real-world problems, which give students a sense of responsibility (Huber, 2005). The means of action of this pedagogy is based on the motivation of the pupils. More importantly, pupils feel concerned and involved in the task (Bensalem, 2010). Larmer and Mergendoller (2010) point out that a project must have an educational purpose and must be perceived by students as an important and enjoyable task. In the project- based approach, the teacher has an accompanying role. He/she organizes activities, brings a variety of tools and discusses with the learners the methodology of the lesson.

\section{Problem Solving Approach}

A problem can be defined as a situation in which the organism has a purpose but does not know the means of achieving it. It is made up of data, goals and obstacles (Dupays, 2011). According to Poirier- Proulx (1999), Three attributes characterize a problem to solve:

- the existence of a gap between the present situation and a desired situation or goal ;

- the absence of a clear path leading to the reduction of this gap ;

- the subjective nature of problem solving. A situation is a problem for a given person at some point.

The problem solving approach was developed in 1969 by Howard Barrow and his colleagues in Canada. This approach is increasingly used in areas where it is impossible for students to master all the knowledge in the field within a limited time frame. Studies have shown that students find learning difficult with the problem solving approach. In this latter, students work in groups facing a problem and try to access new information that could lead to the resolution of this problem (Robardet, 1990, 1995, 2001). Despite this, Van Barneveld (2009) found that problem-based learning is effective in developing skills and improving students' attitudes toward learning. In this approach, the problem-solving phase is vital. Indeed, pupils, who actively participate in the construction of various problems in the classroom, will be involved in solving these problems (Boilevin, 2005). Also, the role of the teacher in this approach is essential; it facilitates and guides the learning process.

\section{Historical Investigation Approach}

The marriage between the historical approach and the investigative approach gave birth to the "Historical-Investigative" approach. In this section, we briefly discuss the literature of the historical approach, the investigative approach and the Historical Investigation approach. 


\subsection{Historical Approach}

Learning theories and pedagogical approaches do not exclude integrating the historical dimension of science into the learning process. However, school curricula in the physical sciences do not provide enough information on the history of the concepts studied. To approach the sciences from a historical point of view gives them a more anchored sense and make the so called "hard sciences" more attractive and more human. In this respect, Bacon announces: the knowledge which would be given as a thread to be extracted again, it would be necessary to transmit it and to make it understood if possible in the very way in which it was discovered (Bacon, 1991). Going back in history brings together the past and the present, exposing the class to knowledge and establishing a relationship of equality between the teacher and the student.

Didactics perceive the strong relationship between the historical approach and the epistemological obstacles of Bachelard. This relationship helps identify barriers associated with learning and knowledge to be taught in the school context (Johsua \& Dupin, 1993). A well-prepared question that revolves around the proximal area of student development, and which causes a debate in the classroom can identify the barriers of these students. From this debate scheduled, the teacher designs a learning pathway which leads the class to the construction of new knowledge (Guedj, 2005).

The historical approach that goes back to the origin of the sciences can only be beneficial to the teaching / learning process independently of the choice of the learning theory. It aims at motivating students, fighting against pupils' fear of scientific disciplines and presenting knowledge in a more entertaining way. The aim of this approach is to supplement traditional education and not replacing it. This approach persists in positing the history of science as the chocolate on cake of teaching (Guedj \& Dusseau, 1999).

However, the in-service training of teachers and their own interest in the epistemology of their discipline are essential to successfully integrate the historical approach into their professional practices. Thus, good preparation for integrating the historical dimension into the teaching/ learning process is necessary to help learners build their own knowledge.

\subsection{Investigation procedure}

The investigation process is relatively new for the teaching of physics. It is part of so-called active learning where the learner is a researcher able to solve problems. Among the main goals of the investigative approach is to deal with the disaffection of students with scientific studies (Rocard et al., 2007), to increase their autonomy and give them the opportunity to choose, argue and discuss the validity of their results (Dumas-Carré \& Weil-Barais, 1998). The investigative approach is defined as an intentional process of diagnosing problems, criticizing experiments to distinguish between alternatives, planning research, assuming research, searching for information, hypothesis research, constructing models, debating with peers and formulating coherent arguments (Rocard et al., 2007). The investigative approach combines the following attributes (Grangeat, 2013) :

- the resolution of problems having an open character;

- research and experimentation ;

- a possibility of self-regulation of learning by offering a high degree of autonomy to learners;

- supporting the scientific debates between learners.

According to Calmettes (2010), the investigative approach is presented by seven steps:

1. the teacher defines a problem situation based on the needs of his / her learners and his / her teaching project;

2. The formulation of student questioning;

3. The formulation of explanatory hypotheses;

4. The design of the investigation process to validate or reject hypotheses;

5. Students' investigation which can take several forms (experimentation, documentary research, etc.);

6. The acquisition and structuring of knowledge under the guidance of the teacher; 
7. Operationalization of knowledge.

Windschitl (2003)described several levels of investigation in science:

- Teacher-led Investigation: Teacher gives students steps to experiment ad verify laws;

- Structured Investigation: The teacher presents a question, materials and procedures for students to discover a new result;

- Guided Investigation: the teacher allows students to investigate a given problem using their own methods of data collection and analysis;

- Student-led Investigation: the teacher presents a topic and students develop their own questions and design their own investigations.

- Open Investigation: At this level, students form their own questions and design their own investigations.

\subsection{Historical Investigation}

The concept of the Historical Investigation approach $(\mathrm{IH})$ in educational sciences was introduced by Kipnis. According to his theory, learning science, in a context of history, should be mastered by practical investigations of students (Kipnis, 1996). The basic idea of this approach is producing results by students who experiment (who are not guided at all) while learning science with his history context (Teichmann, 1999).

The main objectives of this approach are to broaden students' understanding of scientific concepts and theories, develop procedural knowledge, promote their interest in science and to open up the history of science (Heering \& Höttecke, 2014). According to the same authors, the IH approach is characterized by a balance between the following aspects:

- Locating science in the historical context;

- Insisting on the material, social and cultural aspects of science;

- Considering the nature of the sciences taught in the teaching/ learning process;

- Allowing students a hands-on exploration "free" of the phenomena studied;

- The learners' investigation is based on the experiences that have taken place in the past;

- Activating students' critical reflection of their own actions of learning, the sense of their experiences and their reasoning abilities.

According to Kipnis (2002) science students prefer to imitate scientifics and their experiences. He suggested that several modifications should be allowed to be made to these experiments. Thus, using the $\mathrm{HI}$ approach, students begin their own investigations from a historical context instead of repeating an experiment. Kipnis points out that through this approach, students have the chance to become real scientists. In the same vision, Lin and his colleagues (2002) appreciate IH approach that allows students to learn how scientists emit assumptions and how they conduct experiments to validate them.

Moreover, Kipnis (2002)suggests a fairly strict structure for integrating the experimental activities in historical contexts. According to his strategy, during an investigation, students formulate a problem based on a specific historical context. Then, they must identify and select the relevant variables. These variables must be independently examined in order to test a hypothesis. Finally, students should draw general conclusions based on their analysis of the variables and their effect on the phenomenon under study.

\section{Discussion}

In the learning process, the educational quality of the investigation is valued by several researches (Chekour, Laafou, \& Janati-Idrissi, 2017a; Grangeat, 2013; Tinas, 2013) . Thus, the added value of experiments in the learning of science is an indisputable fact, but that of virtual simulation is criticized by several researchers (De Jong, Linn, \& Zacharia, 2013). However, laboratory experiments and virtual simulations can achieve similar goals, such as developing teamwork skills, increasing students' interest in science, increasing conceptual understanding and developing investigative skills (Chekour, Laafou, \& Janati-Idrissi, 2017b; Winsberg, 2003). Smetana and Bell 
(2012) have examined sixty-one studies on the effectiveness of the simulation of learning the physical sciences. The results of this head study show that the simulations are more effective than traditional methods for learning the physical sciences. Other studies confirm that the combination of computer simulation and traditional education may be the most effective strategy for teaching science subjects (Z. Zacharia, 2003; Z. C. Zacharia, 2005; Z. C. Zacharia, Olympiou, \& Papaevripidou, 2008). According to these studies, this strategy allows learners to access laboratory materials and take advantage of the various benefits of simulation.

The historical approach can be used in the presence of simulation software. Indeed, with a simulation software, students can easily evaluate their own assumptions by changing the settings of the phenomena studied without the need of any hardware implementation. In addition, the integration of simulation in the teaching of physics in the presence of $\mathrm{H}$ approach provides an opportunity for learners to identify problems to solve, virtually perform the experiments to validate or reject their assumptions, analyze and discuss the results with their peers. With this techno educational tool, teachers of the physical sciences can give more and more freedom to their pupils especially at the level of proposition of virtual experiments to validate their hypotheses. Of course, this is not evident for the experimental activities of the laboratory. Indeed, some errors of the learners at the level of manipulation of the apparatus of the laboratory can pose a serious danger for their peers.

\section{Conclusion}

The multiplicity of different paradigms shows that learning is not a process easily modelable. However, the act of learning is a common activity. Each paradigm brings relevant considerations to learning, but can not unilaterally impose itself on the didactics of teaching a discipline, in particular to the didactics of the physical sciences (Tinas, 2013). The historical investigation approach seems to be consistent with the needs of students and the experimental nature of the physical sciences. In addition, the $\mathrm{HI}$ approach may include, but is not limited to, the goal-based approach, the competency-based approach, the project-based approach and the problem-solving approach. Hence, the richness of this approach. Indeed, the problem situation that aims at the attainment of an educational objective is among the key moments of the $\mathrm{HI}$ approach. Thus, teachers, who adopt this approach, can propose projects that aim at the realization of certain simulation (of some phenomena) in order to encourage autonomy in their students. Moreover, the $\mathrm{HI}$ approach allows, in the presence of simulation, the development of investigative skills, for example, observation of phenomena, formulation of hypotheses and interpretation of results (Droui \& El Hajjami, 2014). In short, the combination of traditional teaching based on experimental activities, the $\mathrm{HI}$ approach and the integration of simulation can be the most effective strategy for teaching the physical sciences. However, this strategy needs continuous trainings in educational science and the integration of simulation for physics' teachers.

\section{References}

Bacon, F. (1991). Du progrès et de la promotion des savoirs, traduit par M. Le Dø Euff, Paris, Gallimard.

Bates, A. T. (2015). Teaching in a digital age. Glokalde, 1(3). Retrieved from http://dergipark.ulakbim.gov.tr /glokalde/article/view/5000135229

Bensalem, D. (2010). En quoi la pédagogie de projet permet-elle de donner du sens à l'enseignement du français? Synergies Algérie, (9), 75-82.

Boilevin, J.-M. (2005). Enseigner la physique par situation problème ou par problème ouvert. Aster, 2005, 40" Problème et Problématisation". Retrieved from http://documents.irevues.inist.fr/handle/2042/8854

Calmettes, B. (2010). Analyse didactique pragmatique de pratiques en démarche d'investigation en physiqueRapports pragmatiques à l'enseigner-Exemples. In Analyse pragmatique didactique de pratiques et de discours d'enseignants (pp. 1-11). Retrieved from https://halshs.archives-ouvertes.fr/halshs-00551252/

Carette, V. (2008). Les caractéristiques des enseignants efficaces en question. Revue française de pédagogie. Recherches en éducation, (162), 81-93. https://doi.org/10.4000/rfp.851 
Carette, V., Defrance, A., \& Kahn, S. (2006). Les compétences à l'école: apprentissage et évaluation. De Boeck. Retrieved from http://books.google.com/books?hl=fr\&lr=\&id=54e2q17elFoC\&oi=fnd\&pg=PA5\&dq= Les+comp \%C3\%A9tences+\%C3\%A0+|\%E2\%80\%99\%C3\%A9cole:+apprentissage+et+\%C3\%A9valuatio n\&ots=jWyot3Mx5_\&sig=elJPqUrtuzSbLIO-TI7ECqNFjgU

Chekour, M., Laafou, M., \& Janati-Idrissi, R. (2015a). Distance Training for Physics Teachers in Pspice Simulator. Mediterranean Journal of Social Sciences, 6(3 S1), 232.

Chekour, M., Laafou, M., \& Janati-Idrissi, R. (2015b). Les facteurs influençant l'acquisition des concepts en électricité. Cas des lycéens marocains. Adjectif [En Ligne]. Retrieved from http://www.adjectif.net/spip/spip.php?article354

Chekour, M., Laafou, M., \& Janati-Idrissi, R. (2017a). Élaboration d'un scénario d'intégration du simulateur PSPICE dans l'enseignement des concepts électriques à l'aide de la démarche d'investigation. Info-Crde, (20).

Chekour, M., Laafou, M., \& Janati-Idrissi, R. (2017b). Impact de la simulation sur l'acquisition des concepts en électricité: cas des lycéens marocains, 6(8).

De Jong, T., Linn, M. C., \& Zacharia, Z. C. (2013). Physical and virtual laboratories in science and engineering education. Science, 340(6130), 305-308.

Droui, M., \& El Hajjami, A. (2014). Simulations informatiques en enseignement des sciences: Apports et limites. EpiNet, (164). Retrieved from http://www.epi.asso.fr/revue/articles/a1404e.htm

Dumas-Carré, A., \& Weil-Barais, A. (1998). Les interactions didactiques: Tutelle et/ou Médiation. Tutelle et Médiation Dans l'Éducation Scientifique (1-15). Berne: Peter Lang.

Dupays, A. (2011). Apprentissage en résolution de problèmes: influence du mode d'instruction. Besançon. Retrieved from http://www.theses.fr/2011BESA1005

Fayolle, A., \& Verzat, C. (2009). Pédagogies actives et entrepreneuriat: quelle place dans nos enseignements? Revue de l'Entrepreneuriat, 8(2), 1-15.

Grangeat, M. (2013). Modéliser les enseignements scientifiques fondés sur les démarches d'investigation: développement des compétences professionnelles, apport du travail collectif. In In M. Grangeat (Ed.), Les enseignants de sciences face aux démarches d'investigation (Grenoble: Presses Universitaires, pp. 155-184). Retrieved from http://webcom.upmf-grenoble.fr/sciedu/grangeat/Ref/2013_PUG_Chapitre Grangeat.pdf

Griethuijsen, R. A. L. F. van, Eijck, M. W. van, Haste, H., Brok, P. J. den, Skinner, N. C., Mansour, N., ... BouJaoude, S. (2015). Global Patterns in Students' Views of Science and Interest in Science. Research in Science Education, 45(4), 581-603. https://doi.org/10.1007/s11165-014-9438-6

Guedj, M. (2005). Utiliser des textes historiques dans l'enseignement des sciences physiques en classe de seconde des lycées français. Didaskalia, (26), 75-95.

Guedj, M., \& Dusseau, J.-M. (1999). À propos d'une formation des enseignants de sciences physiques à l'épistémologie et à l'histoire des sciences. Bulletin de l'Union Des Physiciens, (815), 991-1005.

Heering, P., \& Höttecke, D. (2014). Historical-investigative approaches in science teaching. In International handbook of research in history, philosophy and science teaching (pp. 1473-1502). Springer. Retrieved from http://link.springer.com/chapter/10.1007/978-94-007-7654-8_46

Hofstein, A. (2017). The Role of Laboratory in Science Teaching and Learning. In Science Education (pp. 357368). SensePublishers, Rotterdam. https://doi.org/10.1007/978-94-6300-749-8_26

Huber, M. (2005). Apprendre en projets: la pédagogie du projet-élèves. Chronique sociale.

Johsua, S., \& Dupin, J.-J. (1993). Introduction à la didactique des sciences et des mathématiques (Vol. 327). Presses universitaires de France Paris. Retrieved from http://publimath.irem.univmrs.fr/biblio/PCL99014.htm

Kipnis, N. (1996). The 'historical-investigative'approach to teaching science. Science \& Education, 5(3), 277292.

Kipnis, N. (2002). A history of science approach to the nature of science: Learning science by rediscovering it. In The nature of science in science education (pp. 177-196). Springer Netherlands. Retrieved from http://link.springer.com/chapter/10.1007/0-306-47215-5_10

Larmer, J., \& Mergendoller, J. R. (2010). Seven essentials for project-based learning. Educational Leadership, 68(1), 34-37.

Lasnier, F. (2000). Réussir la formation par compétences. Montreal: Guérin.

Leal, S. C., Leal, J. P., \& Fernandes, H. (2010). e-lab: a valuable tool for teaching. Contemporary Issues in Education, 1(2), 167-174.

Legendre, M.-F. (1994). Problématique de l'apprentissage et de l'enseignement des sciences au secondaire: un état de la question. Revue Des Sciences de l'éducation, 20(4), 657-677.

Lin, H., Hung, J., \& Hung, S. (2002). Using the history of science to promote students' problem-solving ability. International Journal of Science Education, 24(5), 453-464. 
Ma, H., Fulmer, G. W., \& Liang, L. L. (2017). Science Teaching Practices in Junior Secondary Schools. In Chinese Science Education in the 21st Century: Policy, Practice, and Research (pp. 85-100). Springer, Dordrecht. https://doi.org/10.1007/978-94-017-9864-8_4

Mager, R. F., \& Décote, G. (1971). Comment définir des objectifs pédagogiques. Gauthier-Villars, Paris. Retrieved from http://bu.u-bourgogne.fr/clientbookline/service/reference.asp?output=portal\&instance= exploitation\&docbase $=$ catalogue $\&$ docid $=690085$

Poirier-Proulx, L. (1999). La résolution de problèmes en enseignement: cadre référentiel et outils de formation. De Boeck Université.

Raynal, F., Rieunier, A., Postic, M., \& Françaises, E. S. (1997). Pédagogie: Dictionnaire des concepts clés: Apprentissages, formation, psychologie cognitive. Issy-les-Moulineaux: ESF. Retrieved from http://scd.ubourgogne.fr/clientBookline/service/reference.. asp? instance=exploitation\&output=portal\&docid=673651\&d ocbase $=$ catalogue

Robardet, G. (1990). Enseigner les sciences physiques à partir de situations-problèmes. Bulletin de l'Union Des Physiciens, 720, 17-28.

Robardet, G. (1995). Situations-problèmes et modélisation; l'enseignement en lycée d'un modèle newtonien de la mécanique. Didaskalia, (7), 129-143.

Robardet, G. (2001). Quelle démarche expérimentale en classe de physique? Notion de situation-problème. Bulletin de l'Union Des Physiciens, 836, 1173-1190.

Rocard, M., Csermely, P., Jorde, D., Lenzen, D., Walberg-Henriksson, H., \& Hemmo, V. (2007). L'enseignement scientifique aujourd'hui: une pédagogie renouvelée pour l'avenir de l'Europe. Commission Européenne, Direction générale de la recherche, Science, économie et société.

Sardo-Brown, D. (1990). Experienced teachers' planning practices: A US survey. Journal of Education for Teaching, 16(1), 57-71.

Smetana, L. K., \& Bell, R. L. (2012). Computer simulations to support science instruction and learning: A critical review of the literature. International Journal of Science Education, 34(9), 1337-1370.

Strobel, J., \& van Barneveld, A. (2009). When is PBL more effective? A meta-synthesis of meta-analyses comparing PBL to conventional classrooms. Interdisciplinary Journal of Problem-Based Learning, 3(1), 4.

Taber, K. S. (2017). The Nature of Student Conceptions in Science. In Science Education (pp. 119-131). SensePublishers, Rotterdam. https://doi.org/10.1007/978-94-6300-749-8_9

Teichmann, J. (1999). Studying Galileo at secondary school: A reconstruction of his 'jumping-hill'experiment and the process of discovery. Science \& Education, 8(2), 121-136.

Tinas, J. (2013). Apprentissage d'un concept scientifique: statut de l'hypothese dans la demarche d'investigation en sciences physiques (thèse de doctorat). Université Bordeaux 2. Retrieved from http://www.theses.fr/2013BOR22051

Windschitl, M. (2003). Inquiry projects in science teacher education: What can investigative experiences reveal about teacher thinking and eventual classroom practice? Science Education, 87(1), 112-143.

Winsberg, E. (2003). Simulated experiments: Methodology for a virtual world. Philosophy of Science, 70(1), $105-125$.

Zacharia, Z. (2003). Beliefs, attitudes, and intentions of science teachers regarding the educational use of computer simulations and inquiry-based experiments in physics. Journal of Research in Science Teaching, 40(8), 792-823.

Zacharia, Z. C. (2005). The impact of interactive computer simulations on the nature and quality of postgraduate science teachers' explanations in physics. International Journal of Science Education, 27(14), 1741-1767.

Zacharia, Z. C., Olympiou, G., \& Papaevripidou, M. (2008). Effects of experimenting with physical and virtual manipulatives on students' conceptual understanding in heat and temperature. Journal of Research in Science Teaching, 45(9), 1021-1035. 